\title{
Sınav stresi olan lise son sını öğrencilerinin kahve tüketimi ve beslenme durumunun değerlendirilmesi
}

Gülcan YILDIZ*, Emel ALPHAN**

\section{ÖZET}

Amaç: $\mathrm{Bu}$ çalışma lise son sınıf öğrencilerinde sınav stresiyle artan kafein alımında; ortalama kafein alımını, kafeinin kaynağını, öğrencilerin beslenme durumlarını ve beden kütle indekslerini (BKİ) değerlendirmek amacıyla yapılmıştır. Yöntem: Çalışma Antalya ilinde yer alan bir Anadolu Lisesinde son sınıfta okuyan 109 öğrenci üzerinde gerçekleştirilmiştir. Öğrencilerin beslenme bilgi durumlarını saptamak, günlük kafein alımları ve su tüketimlerini değerlendirmek için 24 saatlik besin tüketimini sorgulayan anket uygulanmıştır. Bulgular: Çalışmaya katılan kadın öğrencilerin BKİ ortalaması $22.48 \pm 3.78 \mathrm{~kg} / \mathrm{m} 2$, erkek öğrencilerin $23.33 \pm 4.04 \mathrm{~kg} / \mathrm{m} 2$ olarak belirlenmiştir. Öğrencilerin kafeini en çok kahveden, daha sonra ise çaydan aldıkları saptanmıştır. Kahve tüketen kız öğrencilerin günlük ortalama kafein alımı $154 \pm 165.29 \mathrm{mg}$, erkek öğrencilerin ise $201.35 \pm 221.84 \mathrm{mg}$ kafein aldığı saptanmıştır. Öğrencilerin günlük ortalama su tüketimi $1487.6 \pm 902.2 \mathrm{ml}$ olup öğrencilerin günlük diyetle aldıkları; enerji, posa, E vitamini, folat ve kalsiyumun, önerilen miktardan daha az olduğu; protein, A vitamini, C vitamini, demir ve çinkonun önerilen miktarları karşıladığı görülmüştür. BKİ'ye göre, çok zayıf olan kız öğrencilerin kafein tüketim ortalamasının fazla olduğu ve istatistiksel olarak anlamlı olduğu saptanmıştır. BKİ'ye göre zayıf olan erkek öğrencilerin günlük kafein tüketim ortalamasının diğer gruplardan daha yüksek olduğu, ancak istatistiksel olarak anlamlı fark olmadığı belirlenmiştir. Sonuç: Sınav stresi olan lise son sınıf öğrencilerinin iyi bir beslenme alışkanlığı kazanması, enerji ve besin ögelerini yeterli düzeyde içeren bir diyet uygulaması, hem fiziksel, gelişimleri hem de okul başarıları için önemlidir. Öğrencilerin kafein tüketimleri ve kafein alımlarının BKİ üzerine etkisini belirleyecek daha fazla çalışmaya ihtiyaç vardır.

Anahtar kelimeler: Adölesan, beslenme, kafein

\section{Evaluation of coffee consumption and nutritional status of high school senior students with exam stress}

\section{ABSTRACT}

Objective: In this study, increased caffeine intake of high school senior students with university entrance exam stress; their mean caffeine intake, their caffeine source, nutritional status and body mass index (BMI) were evaluated. Methods: The study was carried out on 109 high school senior students attending an Anatolian High School in Antalya. In order to determine the nutritional status of the students, to evaluate the daily caffeine intake and water consumption, a questionnaire was formed to question the 24-hour food consumption of the students was applied. Results: The mean BMI of female students was $22.48 \pm 3.78 \mathrm{~kg} / \mathrm{m} 2$ and $23.33 \pm 4.04 \mathrm{~kg} / \mathrm{m} 2$ for male students. Most of their caffeine intake was obtained firstly from coffee and then secondly tea. The average daily caffeine intake of female students consuming coffee was found to be $154 \pm 165.29 \mathrm{mg}$ and the average daily caffeine intake of male students was found to be $201.35 \pm 221.84 \mathrm{mg}$ of caffeine. The average daily water consumption of the students was $1487.6 \pm 902.2 \mathrm{ml}$. The students' energy, pulp, vitamin E, folate and calcium intake is less than the recommended amount; Their protein, vitamin $\mathrm{A}$, vitamin $\mathrm{C}$, iron and zinc intake is at the recommended level. According to BMI, skinny female students have higher caffeine consumption and it was statistically significant. The mean daily caffeine consumption of the skinny male students was higher than other groups, but it was not statistically significant. Conclusion: It is important for high school senior students who have test stress to gain a good nutrition habit In addition, it is important for them to adopt a diet that includes energy and nutrients at a sufficient level for both their physical development and school success. Further studies are needed to determine the effect of caffeine consumption and caffeine intake on BMI of students.

Keywords: Adolescence, caffeine, nutrition

\footnotetext{
Geliş Tarihi: 20.05.2019 Kabul Tarihi:22.06.2019

* İstanbul Okan Üniversitesi, Sağlık Bilimleri Fakültesi, Beslenme ve Diyetetik Bölümü, İstanbul, Türkiye e-mail: dytgulcanyildiz@gmail.com, https://orcid.org/0000-0003-1958-2322

** İstanbul Okan Üniversitesi, Sağlık Bilimleri Fakültesi, Beslenme ve Diyetetik Bölümü, İstanbul, Türkiye e-mail: emel.alphan@okan.edu.tr, https://orcid.org/0000-0002-9702-1881

Sorumlu Yazar/Correspondence: Gülcan Yıldız dytgulcanyildiz@gmail.com
}

Çalışma yüksek lisans tezinden türetilmiștir.

Atıf: Yıldız G, Alphan E Sınav stresi olan lise son sınıf öğrencilerinin kahve tüketimi ve beslenme durumunun değerlendirilmesi. Sağllk ve Yaşam Bilimleri Dergisi 2019;1(1):13-20.

Citation:.Y1ldı G, Alphan E. Evaluation of coffee consumption and nutritional status of high school senior students with exam stress. Journal of Health and Life Science 2019;1(1):13-20. 


\section{GíRIŞ}

Kahve bitkisi yüksek rakımlarda yetişen çok yıllık bir ağaçtır ve kahve dünyada en çok tüketilen içeceklerdendir. ${ }^{1}$ Dünyada yaklaşık her yıl 500 milyar bardak kahve tüketilmektedir. ${ }^{2}$ Kahvenin yapısında bulunan kafein (1, 3, 7-trimetilksantin) alkaloid türevidir. Kafein, mide ve bağırsaklardan hızlıca emilir ve karaciğerde metabolize edilir. ${ }^{3}$ Kahve, stresli durumlarda ve özellikle ders çalışan öğrencilerde uzun süre uyanık kalmayı sağlamak için çok sık tüketilen bir içecektir. Kahvenin sağlık üzerine olumlu ya da olumsuz etkileri hakkında dünya üzerinde birçok araştırma yapılmıştır ancak kahvenin sağlık üzerine olan etkilerinin kahvenin türü, pişirme yöntemi ve tüketim miktarlarına bağlı olarak değişebileceği ileri sürülmektedir. ${ }^{4}$ İnsanlarda, merkezi sinir sistemi stimülasyonu, metabolizma, solunum hızında artış ve diüretik etkileri olan kahvenin özellikle rahatlatma, uyanık tutma ve uyarıcı etkilerinden dolayı tercih edildiği bilinmektedir. $^{5}$

Kafeinin günlük kullanımı >500-600 mg (4-7 kupa) önemli sağlık riski oluşturmaktadır. Kafein alımı ortalama $<400 \mathrm{mg} /$ gün sağlıklı kişi için güvenli görünmekle birlikte bireysel farkl11ıklar olabilmektedir. ${ }^{6}$ Adölesanlarda $>100 \mathrm{mg} /$ gün kafein tüketimi, yüksek kan basıncı ile ilişkilendirilmiştir. Yapılan bir çalışmada, adölesanlar için günlük kafein alımının 100 mg'yi geçmemesi gerektiği bildirilmiştir. $^{7}$ Temple ve arkadaşlarının yaptığı çalışmada, çocuk ve adölesanlarda 100-400 mg kafein alımının sinirlilik, huzursuzluk ve tedirginliğin artmasına, uyuşukluğun azalmasına neden olabildiği saptanmıştır. ${ }^{8}$

Lise son sınıf öğrencileri 17-19 yaşları arasındadır. Dünya Sağlık Örgütü (DSÖ), adölesan dönemini 10-19 yaş olarak belirlemiştir. Stres; bireylerin davranışlarını, başka insanlarla ilişkilerini etkileyebilen kavramdır, sinav stresiyle adölesanların yeme davranışları da etkilenebilmektedir. ${ }^{9}$ Adölesan dönemi ve bebeklik dönemi, büyümenin en hızlı gerçekleştiği önemli bir evredir. Büyüme için artan enerji ve besin öğelerinin gereksinimi, beslenme alışkanlıkları, yaşam tarzı ve çevresel etkilere duyarlılıklarından dolayı toplumda risk grupları içinde yer almaktadır. $\mathrm{Bu}$ nedenle insan beslenmesinin en önemli konularından biri de adölesanların beslenme durumunun değerlendirilmesidir. ${ }^{10,11}$

Çocuk ve adölesanların kafein içeren içecek tüketimi ile yüksek beden kütle indeksi (BKI), daha fazla sağliksız besin tüketimi, meyve, sebze ve süt gibi sağlıklı besinlerin daha az tüketimi ile ilişkilendirilmektedir. ${ }^{8}$ Kafein içeren içeceklerin enerji metabolizmasına olan etkileri hakkında yapılan bir çalışmada, kafeinin vücutta yă yakımını sağladığı, kanda trigliserit düzeyini düşürdüğü, kolesterol düzeyini yükselttiği saptanmıştır. Yüz (100) mg kafein tüketiminin iki saat sonunda vücudun enerji harcamasında $\% 16^{\prime}$ llk bir artış sağladığı saptanmış, bu artışın şeker ve yağın daha fazla yıkılmasından kaynaklandığı, bu yüzden zayıflama diyetlerinde şekersiz çayın olumlu etkileri olabileceği sonucuna varılmıştır. ${ }^{12}$ Başka bir çalışmada normal ağırlıktaki kişilere 8 $\mathrm{mg} / \mathrm{kg}$ kafein verilmiş, $4 \mathrm{mg} / \mathrm{kg}$ kafein tüketen ve kafeinsiz kahve tüketen iki grup ile karşılaştırılmıştır. Sonuç olarak enerji harcamasındaki etki ve termik etkiye bakıldığında düzenli kafein alımının ağırlık kaybına neden olabileceği bildirilmiştir. $^{13}$ Literatür bilgileri değerlendirildiğinde, kahve tüketiminin vücut metabolizmasına olan etkisinin karmaşı olduğu görülmektedir.

$\mathrm{Bu}$ araştırma, lise son sınıf öğrencilerinin, üniversite sınavı öncesindeki günlük kahve tüketim miktarları ile bir günde tükettikleri besinlerin enerji/besin öğesi ve BKI değerlerini değerlendirmek amacıyla yapılmıştır.

\section{YÖNTEM}

Tanımlayıcı ve kesitsel olan çalışmanın evrenini Akdeniz ilinde bir Anadolu Lisesinde öğrenim gören toplam 518 öğrenci oluşturmuştur. Örnekleme 9 Mayıs 2018 tarihinde 118 lise son sınıf öğrencisi alınmıştır. Çalışmada, sınav stresi ile kahve tüketiminin artabileceği öngörüldüğünden lise son sınıf öğrencileri çalışma grubuna dahil edilmiştir. Üç kişinin okula gelmemesi, iki kişinin okul takımında olduğu için şehir dışında maça gitmesi, bir kişinin boş anket kağıdı vermesi ve üç kişinin eksik bilgi vermesi sebebiyle toplam 9 öğrenci çalışma dışında bırakılmış olup 109 kişiye ulaşılmıştır.

Çalışmaya katılan öğrencilerin beslenme durumunu değerlendirmek için 24 saatlik besin tüketim kaydı alınmıştır. Araştırmada öğrencilerin sosyodemografik özellikleri, beslenme durumları ve alışkanlıkları ile kafein tüketim sıklığına yönelik bölümlerden oluşan anket formu yüz yüze görüşülerek doldurulmuştur. Adolesanların antropometrik ölçümlerinin değerlendirilmesinde referans olarak Dünya Sağlık Örgütü (DSÖ) 2007 değerleri alınmıştır. ${ }^{14}$

Öğrenciler çalışmaya gönüllü olarak katılmışlar ve onamları alınmıştır. 18 yaşından küçük olanların ailelerinden, bilgilendirme yapıldıktan sonra çalışmayı gönüllülük iç̧erisinde kabul ettiklerine dair "Veli İzin Formu" alınmıştır. Araştırma için 
etik kurul onayı ve İlçe Milli Eğitim Müdürlüğü’nden izin alınmıştır.

Verilerin analizinde SPSS 22.0 programı kullanılmıştır. Öğrencilerin demografik bilgilerinin, sağlık durumlarının, sigara kullanma durumlarının, öğün düzenlerinin, duygusal durum ve stresin yeme davranışlarına etkisinin, son bir yıldaki kahve tüketim miktarlarındaki artışın ve günlük su tüketim miktarının değerleri yüzdelik olarak verilmiştir. Günlük kafein alımları ve besin tüketimlerine ilişkin ortalamaların belirlenmesinde tanımlayıcı istatistiklerden yararlanılmıştır. Öğrencilerin cinsiyetlerine göre BKİ değerlerinin karşılaştırılmasında çapraz tablolar ve Ki-Kare $\left(\mathrm{x}^{2}\right)$ analizi kullanılırken, öğrencilerin BKİ gruplarına göre günlük kafein tüketimlerinin karşılaştırılmasında Kruskal Wallis $\mathrm{H}$ testi kullanılmıştır.

\section{BULGULAR}

Çalışmaya lise son sınıf öğrencilerinden toplam 109 kişi dahil edilmiştir. Öğrencilerin yaş ortalaması 17.66 yıl olup, \%60.6's1 kadın, \%39.4'ü ise erkeklerden oluşmaktadır.

Tablo 1 incelendiğinde, kadın öğrencilerin \%78.8'inde, erkek öğrencilerin \%93'ünde herhangi bir sağlık sorunu bulunmamaktadır. Kadın öğrencilerin \%31'inde demir eksiliği anemisi; erkek öğrencilerde \%33 göz problemleri en s1k görülen sağlık sorunu olarak belirtilmiştir.

Tablo 1. Öğrencilerin sağlık durumları

\begin{tabular}{|l|r|r|r|r|}
\hline \multirow{2}{*}{} & \multicolumn{2}{|c|}{ Kadın } & \multicolumn{2}{c|}{ Erkek } \\
\cline { 2 - 5 } & s & \% & S & \% \\
\hline $\begin{array}{l}\text { Sağlık sorunu olması } \\
\text { durumu }\end{array}$ & & & & \\
\hline Sağlık sorunu olmayan & 52 & 78.8 & $\begin{array}{r}4 \\
0\end{array}$ & 93.0 \\
\hline Sağlık sorunu olan & 14 & 21.2 & 3 & 7.0 \\
\hline Toplam & 66 & 100.0 & 4 & 100.0 \\
\hline $\begin{array}{l}\text { Hekim tarafından tanısı } \\
\text { konulan hastalıklar* }\end{array}$ & & & & \\
\hline Şişmanlık & 2 & 6.9 & 1 & 11.1 \\
\hline Kalp-damar & 4 & 13.8 & - & \\
\hline Diyabet & - & - & 1 & 11.1 \\
\hline Ülser / gastrit / reflü & 3 & 10.3 & 1 & 11.1 \\
\hline $\begin{array}{l}\text { Anemi (Demir / B12 } \\
\text { yetersizliği) }\end{array}$ & 9 & 31.0 & - & \\
\hline $\begin{array}{l}\text { Karaciğer / safra kesesi } \\
\text { hastalıkları }\end{array}$ & 1 & 3.4 & 1 & 11.1 \\
\hline Göz & 7 & 24.1 & 3 & 33.3 \\
\hline Troid & 1 & 3.4 & - & \\
\hline Alerji / astım & 2 & 6.9 & 2 & 22.2 \\
\hline Toplam & 29 & 100.0 & 9 & 100.0 \\
\hline Brim & & & \\
\hline
\end{tabular}

*Birden fazla seçenek ișaretlenmiștir.
Tablo 2'de öğrencilerin beslenme davranışları yer almaktadır. Kadın öğrencilerin \%48.5'inin, erkek öğrencilerin ise \%39.5'inin öğün atladığ 1 belirlenmiştir. Kadın öğrencilerin \%78.1'i, erken öğrencilerin ise \%88.2'si sabah öğününü atlamaktadır. Kadın öğrencilerin \%87.9'u, erkek öğrencilerin \%72.1'i duygusal durumlarının beslenmelerini etkilediğini ifade etmişlerdir. Kadın öğrencilerin \%84.8'i, erkek öğrencilerin ise \%67.4'ü stresin yeme davranışlarını etkilediğini bildirmişlerdir. Stresin yeme davranışını etkilediğini ifade eden kadın öğrencilerin \%50'si daha az yediğini, \%50'si ise daha fazla yediğini ifade etmektedir. Stresin yeme davranışını etkilediğini ifade eden erkek öğrencilerin \%44.8'i daha az yediğini, \%55.2'si daha fazla yediğini belirtmişlerdir.

Tablo 2. Öğrencilerin beslenme davranıșları

\begin{tabular}{|c|c|c|c|c|}
\hline & \multicolumn{2}{|c|}{ Kadın } & \multicolumn{2}{|c|}{ Erkek } \\
\hline & $\mathbf{s}$ & $\%$ & $\mathbf{s}$ & $\%$ \\
\hline \multicolumn{5}{|l|}{$\begin{array}{l}\text { Günlük ana öğün } \\
\text { sayısı }\end{array}$} \\
\hline 1 öğün & 2 & 3.0 & - & - \\
\hline 2 öğün & 17 & 25.8 & 8 & 18.6 \\
\hline 3 öğün & 47 & 71.2 & 35 & 81.4 \\
\hline Toplam & 66 & 100.0 & 43 & 100.0 \\
\hline \multicolumn{5}{|l|}{$\begin{array}{l}\text { Günlük ara öğün } \\
\text { sayısı }\end{array}$} \\
\hline 1-3 ara öğün & 55 & 96.5 & 29 & 87.9 \\
\hline 4-5 ara öğün & 2 & 3.5 & 4 & 12.1 \\
\hline Toplam & 57 & 100.0 & 33 & 100.0 \\
\hline \multicolumn{5}{|c|}{ Atlanan öğün var mı } \\
\hline Evet & 32 & 48.5 & 17 & 39.5 \\
\hline Hayır & 34 & 51.5 & 26 & 60.5 \\
\hline Toplam & 66 & 100.0 & 43 & 100.0 \\
\hline \multicolumn{5}{|l|}{ Atlanan öğün } \\
\hline Sabah & 25 & 78.1 & 15 & 88.2 \\
\hline Öğle & 4 & 12.5 & - & - \\
\hline Akşam & 3 & 9.4 & 2 & 11.8 \\
\hline Toplam & 32 & 100.0 & 17 & 100.0 \\
\hline \multicolumn{5}{|c|}{$\begin{array}{l}\text { Duygusal durum } \\
\text { beslenmeyi etkiler } \\
\text { mi? }\end{array}$} \\
\hline Evet & 58 & 87.9 & 31 & 72.1 \\
\hline Hayır & 8 & 12.1 & 12 & 27.9 \\
\hline Toplam & 66 & 100.0 & 43 & 100.0 \\
\hline \multicolumn{5}{|c|}{$\begin{array}{l}\text { Stres yeme } \\
\text { davranışını etkiler } \\
\text { mi? }\end{array}$} \\
\hline Evet & 56 & 84.8 & 29 & 67.4 \\
\hline Hayır & 10 & 15.2 & 14 & 32.6 \\
\hline Toplam & 66 & 100.0 & 43 & 100.0 \\
\hline \multicolumn{5}{|c|}{$\begin{array}{l}\text { Stresin yeme } \\
\text { davranışına etkisi }\end{array}$} \\
\hline Daha az yiyen & 28 & 50.0 & 13 & 44.8 \\
\hline Daha fazla yiyen & 28 & 50.0 & 16 & 55.2 \\
\hline Toplam & 56 & 100.0 & 29 & 100.0 \\
\hline
\end{tabular}


Tablo 3 incelendiğinde, kadın öğrencilerin \%89.4'ünün, erkek öğrencilerin ise \%88.4'ünün kahve tükettiği görülmektedir. Kadın öğrencilerin \%67.8'i, erkek öğrencilerin \%71.1'i kahveyi akşam vakti tüketmektedir. Kahve tüketen kadın öğrencilerin \%62.7'si kahve ile birlikte çikolata tüketirken, \%23.7'si lokum tüketmekte ve \%13.6's1 her ikisini birlikte tüketmektedir. Kahve tüketen erkek öğrencilerin \%48.6'sı kahve ile birlikte çikolata tüketirken, \%24.3'ü lokum tüketmekte ve $\% 27$ 'si her ikisini de birlikte tüketmektedir. Kadın öğrencilerin \%62.7'si erkek öğrencilerin \%44.7'si son bir yıl içerisinde kahve tüketimlerinin arttığını bildirmişlerdir.

Tablo 3. Öğrencilerin kahve tüketim durumları

\begin{tabular}{|c|c|c|c|c|}
\hline & \multicolumn{2}{|c|}{ Kadın } & \multicolumn{2}{|c|}{ Erkek } \\
\hline & $\mathbf{s}$ & $\%$ & $\mathbf{s}$ & $\%$ \\
\hline \multicolumn{5}{|c|}{ Kahve tüketme durumu } \\
\hline $\begin{array}{l}\text { Kahveyi } \\
\text { tüketmeyen }\end{array}$ & 7 & 10.6 & 5 & 11.6 \\
\hline Kahveyi tüketen & 59 & 89.4 & 38 & 88.4 \\
\hline Toplam & 66 & 100.0 & 43 & 100.0 \\
\hline \multicolumn{5}{|c|}{ Kahve tüketilen öğün } \\
\hline Sabah & 14 & 23.7 & 4 & 10.5 \\
\hline Öğlen & 5 & 8.5 & 7 & 18.4 \\
\hline Akşam & 40 & 67.8 & 27 & 71.1 \\
\hline Toplam & 59 & 100.0 & 38 & 100.0 \\
\hline \multicolumn{5}{|c|}{ Kahve ile birlikte tüketilen tatlı/tatlılar } \\
\hline Çikolata & 37 & 62.7 & 18 & 48.6 \\
\hline Lokum & 14 & 23.7 & 9 & 24.3 \\
\hline Her ikisi & 8 & 13.6 & 10 & 27.0 \\
\hline Diğer & 0 & 0 & 1 & 2,7 \\
\hline Toplam & 59 & 100.0 & 37 & 100.0 \\
\hline \multicolumn{5}{|c|}{ Son 1 yıl içerisinde kahve tüketiminde artış } \\
\hline Evet & 37 & 62.7 & 17 & 44.7 \\
\hline Hayır & 22 & 37.3 & 21 & 55.3 \\
\hline Toplam & 59 & 100.0 & 38 & 100.0 \\
\hline
\end{tabular}

Kadın öğrencilerin günlük ortalama kafein tüketim miktarının $154 \pm 165.29 \mathrm{mg}$, erkek öğrencilerin ise $201.35 \pm 221.84 \mathrm{mg}$ olduğu saptanmıştır. Kadın öğrencilerin kahveden aldıkları günlük kafein ortalaması $84.94 \pm 149.62 \mathrm{mg}$, erkek öğrencilerin $61.20 \pm 82.82 \mathrm{mg}$ 'dır. Erkek öğrencilerin çay, kola ve enerji içeceklerinden aldıkları kafein ortalaması kadın öğrencilerden istatistiksel olarak anlamlı düzeyde daha yüksektir $(\mathrm{p}<0.05)$. Buna karşın kahve, sütlü çikolatalı içecekler, çikolata, kakaolu/kahveli bisküvi kek pastalar ve kakaolu/kahveli dondurmadan alınan kafein miktarında cinsiyete göre istatistiksel olarak anlamlı fark saptanmamıştır $(\mathrm{p}>0.05)$.

Öğrencilerin su tüketimlerinin ortalamas1 1487.6 \pm 902.2 ml'dir. Kadın öğrencilerin $\% 53$ 'ünün, erkek öğrencilerin \%32,6'sının günlük 1000 ml'nin altında su tükettiği, kadın öğrencilerin \%37.9'unun, erkek öğrencilerin \%41.9'unun günlük 1000-2000 ml arasında su tükettiği, kadın öğrencilerin \%9.1'inin, erkek öğrencilerin \%25.6'sının günlük 2000 ml'nin üzerinde su tükettiği saptanmıştır. Erkek öğrencilerin su tüketim düzeyleri kadın öğrencilerden istatistiksel olarak anlamlı düzeyde daha yüksektir ( $\mathrm{p}<0.05)$ (Tablo 4).

Tablo 4. Kahve tüketen öğrencilerin günlük kafein tüketim kaynakları ve miktarları*

\begin{tabular}{lccc}
\hline $\begin{array}{l}\text { Kafeinli } \\
\text { içecek } \\
\text { türü }\end{array}$ & $\begin{array}{r}\text { Kadın } \\
\text { Ort } \pm \text { Ss }\end{array}$ & $\begin{array}{r}\text { Erkek } \\
\text { Ort } \pm \text { Ss }\end{array}$ & p \\
\hline Kahve & $84.94 \pm 149.62$ & $61.20 \pm 82.82$ & .394 \\
\hline Çay & $32.62 \pm 30.62$ & $52.98 \pm 53.16$ & .020 \\
\hline $\begin{array}{l}\text { Sütlü } \\
\text { cikolatalı } \\
\text { içecekler }\end{array}$ & $5.57 \pm 7.67$ & $10.25 \pm 16.69$ & .214 \\
\hline Çikolata & $26.18 \pm 26.34$ & $35.75 \pm 69.39$ & .385 \\
\hline Kola & $13.55 \pm 18.16$ & $37.94 \pm 59.80$ & .013 \\
\hline $\begin{array}{l}\text { Kakaolu/ } \\
\text { kahveli } \\
\text { bisküvi } \\
\text { kek } \\
\text { pastalar }\end{array}$ & $7.93 \pm 10.07$ & $17.51 \pm 28.61$ & .052 \\
\hline $\begin{array}{l}\text { Kakaolu } \\
\text { /kahveli } \\
\text { dondurma }\end{array}$ & $2.48 \pm 1.75$ & $2.26 \pm 2.61$ & .762 \\
\hline $\begin{array}{l}\text { Enerji } \\
\text { içecekleri }\end{array}$ & $11.63 \pm 20.19$ & $38.16 \pm 44.22$ & .028 \\
\hline Toplam & $154.00 \pm 165.29$ & $201.35 \pm 221.84$ & .232 \\
\hline *Miktarlar mg olarak belirtilmiştir & & \\
\hline
\end{tabular}

*Miktarlar mg olarak belirtilmiştir.

Tablo 5 incelendiğinde, erkek öğrencilerin vücut ağırlıkları ve BKİ $\left(\mathrm{kg} / \mathrm{boy}^{2}\right)$ değerleri kadın öğrencilerden anlamlı düzeyde daha yüksektir $(\mathrm{p}<0.05)$, buna karşın boy uzunlukları ile cinsiyete arasında istatistiksel olarak anlamlı bir fark bulunmamaktadır $(\mathrm{p}>0.05)$.

Tablo 5. Öğrencilerin antropometrik ölçümleri

\begin{tabular}{lrrr}
\hline $\begin{array}{l}\text { Antropometrik } \\
\text { ölçümler }\end{array}$ & $\begin{array}{r}\text { Kadın } \\
\text { Ort } \pm \text { Ss }\end{array}$ & $\begin{array}{r}\text { Erkek } \\
\text { Ort } \pm \text { Ss }\end{array}$ & p \\
\hline $\begin{array}{l}\text { Boy uzunluğu } \\
(\mathrm{m})\end{array}$ & $1.63 \pm 0.05$ & $1.75 \pm 0.07$ & 0.265 \\
$\begin{array}{l}\text { Vücut ağırlı̆̆ } \\
(\mathrm{kg})\end{array}$ & $59.64 \pm 9.92$ & $71.12 \pm 12.77$ & 0.000 \\
BKI (kg/boy $\left.{ }^{2}\right)$ & $22.48 \pm 3.78$ & $23.33 \pm 4.04$ & 0.000 \\
\hline
\end{tabular}

Kadın öğrencilerin günlük ortalama enerji alımının $1771 \pm 714$ kkal'dir ve Türkiye Beslenme Rehberi'nde önerilen miktarın \%78,3'ünü karşılamaktadır. Erkek öğrencilerin ise günlük ortalama enerji alımının $2129 \pm 777$ kkal olduğu ve önerilen miktarın \%74.4'ünü karşılamakta olduğu görülmektedir. TÜBER'de önerilen günlük alım miktarına göre; kadın öğrencilerin günlük protein alımı ortalama $63.29 \pm 32.64 \mathrm{~g}$ ve $\% 109.1$ 'ini, yağ alımı ortalama $72.90 \pm 36.86 \mathrm{~g}$ ve \%97.2'sini karşılamaktadır. Günlük karbonhidrat alımı ortalama $211.43 \pm 95.65 \mathrm{~g}$ ve önerilen miktarın \%162.6'sını karşılamaktadır. Günlük posa alımı 
ortalama $17.50 \pm 8.73 \mathrm{~g}$ ve önerilen miktarın \%67.3'ünü karşılamaktadır.

Erkek öğrencilerin günlük protein alımı ortalama $85.07 \pm 33.60 \mathrm{~g}$ ve \%125.1'ini, yağ alımı ortalama
$79.17 \pm 34.49$ g ven $\% 83.3$ 'ünü, karbonhidrat alımı ortalama $263.13 \pm 114.54 \mathrm{~g}$ ve $\% 202.4$ 'ünü, günlük posa alımı ortalama $21.18 \pm 13.48 \mathrm{~g}$ ve $\% 73$ 'ünü karşılamaktadır (Tablo 6).

Tablo 6. Öğrencilerin günlük ortalama enerji ve besin öğeleri alımları

*kkal/gün, **g/gün, a $\mu \mathrm{g} /$ gün, bmg/gün

\begin{tabular}{|c|c|c|c|c|c|c|}
\hline Besin öğeleri & $\begin{array}{l}\text { Kadın } \\
\operatorname{Ort} \pm \text { Ss }\end{array}$ & $\begin{array}{r}\text { TÜBER } \\
\text { önerilen } \\
\text { miktar }\end{array}$ & $\begin{array}{r}\text { TÜBER } \\
\text { Önerilen } \\
(\%)\end{array}$ & $\begin{array}{r}\text { Erkek } \\
\text { Ort } \pm \text { Ss }\end{array}$ & $\begin{array}{r}\text { TÜBER } \\
\text { önerilen } \\
\text { miktar }\end{array}$ & $\begin{array}{r}\text { TÜBER } \\
\text { Önerilen } \\
(\%)\end{array}$ \\
\hline Enerji* & $1771 \pm 714$ & 2260 & 78.3 & $2129 \pm 777$ & 2860 & 74.4 \\
\hline Protein** & $63.29 \pm 32.64$ & $57.8-59.3$ & 109.1 & $85.07 \pm 33.60$ & $69.6-66.4$ & 125.1 \\
\hline Yăg** & $72.90 \pm 36.86$ & 75 & 97.2 & $79.17 \pm 34.49$ & 95 & 83.3 \\
\hline Karbonhidrat** & $211.43 \pm 95.65$ & 130 & 162.6 & $263.13 \pm 114.54$ & 130 & 202.4 \\
\hline Posa* & $17.50 \pm 8.73$ & 26 & 67.3 & $21.18 \pm 13.48$ & 29 & 73 \\
\hline A Vitamini $^{\mathrm{a}}$ & $741.36 \pm 391.02$ & 700 & 105.9 & $1281.30 \pm 3071.02$ & 900 & 142.3 \\
\hline E Vitamini $^{b}$ & $10.23 \pm 8.43$ & 15 & 68.2 & $12.02 \pm 10.24$ & 15 & 80.1 \\
\hline $\mathrm{B}_{1}$ Vitamini $^{\mathrm{b}}$ & $0.80 \pm 0.44$ & 1 & 80 & $1.05 \pm 0.58$ & 1.2 & 87.5 \\
\hline $\mathrm{B}_{2}$ Vitamini $^{\mathrm{b}}$ & $0.99 \pm 0.45$ & 1 & 99 & $1.29 \pm 0.74$ & 1.3 & 99.2 \\
\hline $\mathrm{B}_{6}$ Vitamini $^{\mathrm{b}}$ & $1.01 \pm 0.51$ & 1.2 & 84.1 & $1.38 \pm 0.66$ & 1.3 & 106.1 \\
\hline Folat toplam ${ }^{\mathrm{a}}$ & $233.93 \pm 134.86$ & 400 & 58.4 & $314.31 \pm 202.21$ & 400 & 78.5 \\
\hline C Vitamini ${ }^{\mathrm{b}}$ & $76.38 \pm 66.75$ & 75 & 101.8 & $82.19 \pm 77.37$ & 75 & 109.5 \\
\hline Sodyum $^{\mathrm{b}}$ & $4956.81 \pm 11069.99$ & 1500 & 330.4 & $4988.23 \pm 7301.99$ & 1500 & 332.5 \\
\hline Potasyum $^{\mathrm{b}}$ & $2293.29 \pm 1122.47$ & 4700 & 48.7 & $2702.43 \pm 1265.11$ & 4700 & 57.4 \\
\hline Kalsiyum $^{\mathrm{b}}$ & $638.49 \pm 312.45$ & 1300 & 49.1 & $772.47 \pm 413.84$ & 1300 & 59.4 \\
\hline Magnezyum $^{\mathrm{b}}$ & $255.51 \pm 138.27$ & 350 & 73 & $317.86 \pm 157.64$ & 350 & 90.8 \\
\hline Fosfor $^{\mathrm{b}}$ & $1032.48 \pm 575.09$ & 4000 & 25.8 & $1340.17 \pm 541.79$ & 4000 & 33.5 \\
\hline Demir $^{b}$ & $9.69 \pm 6.21$ & 10 & 96.9 & $12.48 \pm 6.04$ & 10 & 124.8 \\
\hline Çinko $^{b}$ & $8.60 \pm 4.19$ & 10 & 86 & $18.51 \pm 44.39$ & 11 & 168.2 \\
\hline
\end{tabular}

Tablo 7 incelendiğinde, BKİ persentil gruplandırmasına göre kadın öğrencilerden çok zayıf olan öğrencilerin günlük kafein tüketim ortalamasının diğer gruplardan daha yüksek olduğu, hafif şişman öğrencilerin en fazla kafein tüketen ikinci grup olduğu ve kadın öğrencilerin BKİ persentil gruplarına göre günlük kafein tüketim miktarlarının istatistiksel olarak anlamlı düzeyde farklılaştığı görülmektedir $(\mathrm{p}<0,05)$. BKİ persentil gruplandırmasına göre erkek öğrencilerden zayıf olan öğrencilerin günlük kafein tüketim ortalamasının diğer gruplardan daha yüksek olduğu, hafif şişman öğrencilerin en fazla kafein tüketen ikinci grup olduğu ancak erkek öğrencilerin BKİ persentil gruplarına göre günlük kafein tüketim miktarlarının istatistiksel olarak anlamlı düzeyde farklılaşmadığg görülmektedir ( $\mathrm{p}>0,05)$.
Tablo 7. Öğrencilerin BKİ persentil gruplarına göre günlük kafein tüketim miktarlarının karşılaştırılması

\begin{tabular}{ccccc}
\multicolumn{4}{c}{ günlük kafein tuketim miktarlarının karşılaştırılması } & \\
\hline $\begin{array}{c}\text { Antropometrik } \\
\text { ölçümler }\end{array}$ & $\begin{array}{c}\text { Kadın } \\
\text { Ort } \pm \text { Ss }\end{array}$ & $\mathbf{p}$ & $\begin{array}{c}\text { Erkek } \\
\text { Ort } \pm \text { Ss }\end{array}$ & p \\
\hline Çok zayıf & $823.00 \pm 0.0$ & & $262.25 \pm 183.233$ & \\
Zayıf & $121.50 \pm 100.415$ & & $329.25 \pm 342.648$ & \\
Normal kilolu & $121.90 \pm 81.835$ & .000 & $193.29 \pm 229.327$ & .493 \\
Hafif şiş̧an & $224.76 \pm 232.434$ & & $263.38 \pm 308.270$ & \\
Şişman & $105.75 \pm 61.376$ & & $100.88 \pm 65.331$ & \\
\hline
\end{tabular}

\section{TARTIŞMA}

Çalışma, lise son sınıf öğrencilerinin, günlük kahve tüketimleri ile bir günde tükettikleri besinlerin enerji ve besin öğesi değerlerini belirlemek, aynı zamanda kafein tüketimi ile BKİ arasındaki ilişkiyi değerlendirmek amacıyla yapılmıştır. 
Gelişmiş bir ülke olan İspanya'da çocuk ve ergenlerin tükettikleri besin öğelerinin önerilen miktarların altında olduğu bildirilmektedir. ${ }^{15}$ Bizim çalışmamızda da benzer sonuçlar elde edilmiştir Ülkemizde yapılan bir çalışmada adölesanların, \%74'ünün sadece 3 öğün yemek yediği, diğerlerinin de günde en az bir öğünü atladığı saptanmıştır. ${ }^{16}$ Başka bir çalışmada, kadınlarda kahvaltıyı atlama oranı \%68 olarak bulunmuş ve bunun fazla kiloluluk ve obezite için risk faktörü olduğu belirtilmiştir. ${ }^{17}$ Adölesanlara düzenli kahvaltı yapma alışkanlığı kazandırılmasının, hayat boyu sağlı̆ğın korunmasında etkili bir alışkanlık olduğu bildirilmiştir. ${ }^{18} \mathrm{Bu}$ çalışmada kadın öğrencilerin daha fazla öğün atladığı, öğün atlayan kadın öğrencilerin \%78.1'inin kahvaltıyı, erkek öğrencilerin ise \%88.2'sinin kahvaltıyı atladığı saptanmıştır.

Alınan besin tüketim kaydı sonunda çalışmamızda, ortalama enerji alımının TÜBER'e göre yetersiz olduğu gözlemlenmiștir. Günlük protein alımı iki grupta da önerilenin üzerinde karşılandığı görülmektedir. $\mathrm{Bu}$ durumun ev dışında yemek yemenin fazla olmasından ve katılımciların çoğunun günde en az bir öğünü dışarıda tüketmesinden kaynaklandığı düşünülmektedir. Çalışmamızda ortalama posa alımı iki grupta da önerilen değerin altındadır, bu durumun ev dışında yemekten kaynaklanabileceği düşünülmektedir. Adölesanlarda vitamin alımı da önemlidir ve bizim çalışmamızda sırasıyla; A vitamini ve $\mathrm{C}$ vitamini alımları iki grupta da önerilen değeri karşılamaktadır. Diğer vitaminlerden E vitamini ve folat alımı ise iki grupta da önerilen değerlerin altındadır. Mineral alımları ise; kalsiyum alımı her iki grupta da önerilen değerin çok altında, demir alımı kadın ögrencilerde önerilen değeri karşılamamakta, erkek öğrencilerde önerilen değerleri karşılamaktadır. Çinko alımı ise, kadın öğrencilerde önerilen değerin altında, erkek öğrencilerde $(18 \mathrm{mg})$ önerilen değerin çok üstündedir.

Günlük sıvı gereksiniminin karşılanması; su içmek, metabolizma sonucu oluşan su ve yiyecekiçeceklerle aldığımız su ile olmaktadır. ${ }^{19}$ Kronik böbrek hastalığı oluşmasında ve yeni başlayan hiperglisemide yetersiz sade su alımının etkili olduğu gösterilmiştir. ${ }^{20} \mathrm{Su}$ alımı erkekler için 2,5 L/gün kadınlar için $2 \mathrm{~L} /$ gün önerilmektedir. ${ }^{21} \mathrm{Bu}$ çalışmada kadın öğrencilerin \%89,9'u, erkek öğrencilerin $\% 74,5$ 'i günlük $2 \mathrm{~L} /$ gün altında su tükettiklerini bildirmişlerdir. Erkek öğrencilerin su tüketim düzeyleri kadın öğrencilerden istatistiksel olarak anlamlı düzeyde daha yüksektir ancak her iki grup içinde su alımının arttırılması önerilmektedir. Adölesanlarda stresli durumlarda daha fazla yemek yeme, daha az yemek yeme, çok fazla kahve tüketme gibi durumlar görülmektedir. ${ }^{9}$ ABD de yapılan araştırmalarda adölesanların günde ortalama 60-70 mg kafein aldıkları, ancak bu miktardaki kafeini, kahve ve çay vb. kafein içeriği yüksek içeceklerden değil gazlı içeceklerden aldıkları bildirilmiştir. ${ }^{7}$ Almanya'da adölesan erkeklerin kafein alımlarının $0,42 \mathrm{mg} / \mathrm{kg}$ olduğu, en yüksek kafein kaynağının da kola ve gazlı içecekler olduğu, daha sonra sırası ile çay, az miktarda alkol içeren meyveli içecekler ve enerji içecekleri olduğu saptanmıştır. ${ }^{22}$ Türkiye'de yapılan bir çalışmada ise adölesanların günlük ortalama kafein alımları 141 $\mathrm{mg} / \mathrm{gün}$ bulunmuş ve bu kafeinin en çok kahve çeşitleri olmak üzere çay çeşitleri ve sütlü çikolatalı içecekler olduğu bulunmuştur. ${ }^{11}$ Literatürde adölesanların en çok tükettiği kafein kaynağının gazlı içecekler olduğu bildirilmiştir. ${ }^{7-22}$ Ülkemizde ise bunun kahve olduğu, 2. sırada ise çayın yer aldığı görülmektedir. ${ }^{11}$

$\mathrm{Bu}$ çalışmada günde ortalama kafein alımının, kahve tüketen kadın öğrencilerde $154 \mathrm{mg} /$ gün, erkek öğrencilerde $201 \mathrm{mg} /$ gün olduğu bulunmuştur. $\mathrm{Bu}$ oran güvenilir alım düzeyinin üzerindedir. Katılımcılardan kahve tüketen kadın öğrencilerin \%62.7'si, kahve tüketen erkek öğrencilerin \%44.7'si son bir yıl içinde daha fazla kafein tükettiklerini bildirmişler. Kafeini öğrenciler en fazla kahveden, daha sonra çaydan aldıklarını bildirmişlerdir. Erkek öğrencilerin çay, kola ve enerji içeceklerinden aldıkları kafein ortalaması kadın öğrencilerden istatistiksel olarak anlamlı düzeyde daha yüksek olduğu saptanmıştır.

Büyümenin izlenmesi, çocuk ve adölesanlarda sağlık ve beslenme durumunu tanımlayan tek göstergedir, beslenmeyi olumsuz etkileyen etmenler çocuğun büyümesini de etkilemektedir. Yaşa göre boy uzunluğu lineer büyümeyi, boy uzunluğuna göre vücut ağıllığı vücut oranlarını ve akut büyüme bozukluklarını ve uzun dönemde büyüme bozukluğunu göstermektedir. Yaşa göre vücut ağırlığ 1 ise hem lineer büyümeyi hem de vücut oranlarını tanımlamaktadır. ${ }^{23,24}$ Ülkemizde Adölesanlarda yapılan bir çalışmada, vücut ağırlığı ortalamas1 $61,1 \mathrm{~kg}$, boy uzunluğu ortalamas1 171,8 $\mathrm{cm}$ ve BKİ ortalamas 1 da $20,7 \mathrm{~kg} / \mathrm{m}^{2}$ olarak ölçülmüşsür. ${ }^{11}$ Bizim çalışmamızda ise, katılımcıların boy uzunluğu ortalaması kadın öğrencilerde $163 \mathrm{~cm}$, erkek öğrencilerde $175 \mathrm{~cm}$, vücut ağırlı̆̆ $\mathrm{kg}$, erkek öğrencilerde $71,1 \mathrm{~kg}$, BKİ ortalamasının ise kadın öğrencilerde $22,48 \mathrm{~kg} / \mathrm{m}^{2}$, erkek öğrencilerde $23,33 \mathrm{~kg} / \mathrm{m}^{2}$ olarak saptanmıştır. Erkek öğrencilerin vücut ağırlıkları ve BKI $\left(\mathrm{kg} /\right.$ boy $\left.^{2}\right)$ değerleri kadın öğrencilerden anlamlı düzeyde daha yüksek, boy uzunlukları cinsiyete göre istatistiksel olarak anlamlı bulunmamıştır. Katılımcıların DSÖ 2007 referans değerleri ile karşılaştırıldığında gruplar arasında yaşa göre ağırlık, boy ve BKİ persentil değerlerindeki fark istatistiksel olarak 
anlamlı bulunmamıştır. Bu çalışmanın sonuçlarında elde edilen antropometrik ölçüm sonuçları diğer çalışmalar ile kıyaslandığında, benzer sonuçlar bulunmuştur.

Kafeinin (özellikle yeşil çayda bulunan kateşin) ağırlık yönetiminde etkili olduğu gösterilmiştir. Enerji dengesi ağırlık yönetiminde önemlidir. Bir çalışmada iki gruba dört haftalık diyet, ardından 13 haftalık süreçte bir gruba yeşil çay (günde 104 $\mathrm{mg} /$ gün) diğerine plasebo verilmiştir ve yeşil çay grubundaki katılımcıların ağırlıklarının \%6,4'ünü kaybettikleri gözlemlenmiştir. ${ }^{13}$ Yapılan bu çalışmada da kadın öğrencilerden çok zayıf olan öğrencilerin günlük kafein tüketim ortalamasının diğer gruplardan daha yüksek olduğu, hafif şişman öğrencilerin en fazla kafein tüketen ikinci grup olduğu ve kadın öğrencilerin BKİ persentil gruplarına göre günlük kafein tüketim miktarlarının istatistiksel olarak anlamlı düzeyde farklılaştığı görülmektedir.

Çalışmanın sınav günü yapılmasına rağmen gelmeyen öğrencilerin bulunması, hatırlanmadığ1 için daha az besin öğesi yazılması çalışmanın sinırlıklarındandır.

\section{SONUÇ}

Lise son sınıf öğrencilerinin sınav sürecinde artan kafein alımı konusunda öğrencilerin ve aileleri bilinçlendirilmeli ve fazla kafein alımının insan sağlığına etkileri konusunda eğitim verilmelidir. Sınav stresi olan lise son sınıf öğrencilerinin iyi bir beslenme alışkanlığı kazanması, enerji ve besin ögelerini yeterli düzeyde içeren bir diyet uygulaması hem gelişimleri hem de okul başarıları için önemlidir. Öğrencilerin kafein tüketimleri ve kafein alımlarının BKİ üzerine etkisini belirleyecek daha fazla çalışmaya ihtiyaç vardır.

\section{KAYNAKLAR}

1. Butt M, Sultan M. Coffee and its consumption: benefits and risks, critical reviews in food. Food Sciences and Nutrition. 2011;51(4):363373.

2. Dorea $\mathrm{J}, \mathrm{G}$ da Costa TM. Is coffee a functional food. Br J Nutr. 2005;93:773-782.

3. Yılmaz E. Kafein alımının metabolik hiz ve enerji harcanışına etkileri. Gıda Müh. Derg. 2001;6:32-37.

4. SözlüS, Yılmaz B, Acar N. Kahve tüketimi ve bazı hastalıklarla ilişkisi. DÜ Sağlık Bil Enst Derg. 2017;8:33-39.

5. Pillay L. A systematic review examining the relationship between coffee consumption and breast cancer. NPHIs. 2013;13(5):28-39.

6. Babu MA, Weil J, Mejia D, Gonzalez E. Caffeine (1,3,7-trimethly xanthine) in foods: a comprehensive review on consumption, functionality, safety and regulatory matters. IFT. 2010;75(3):77-88.

7. Babu KM, Church RJ, Lewander W. Energy drinks: theneweye-opener for adolescents. Clin Pediatr. 2008;9(1):35-42.

8. Temple JL, Dewey AM, Brietico LN. Effects of a caffeine administration on adolescents. Exp Clin Psychopharmacol. 2010;18(6):510-515.

9. Güçlü N. Stres yönetimi. GEFAD. 2001;21(1):91-109.

10. WHO. Nutrition in adolescence- issue and challenges for health sector. İsviçre: World Health Organization Press; 2005.

11. Otman TÖ. Adolesan futbolcuların beslenme durumları ile sıv1 tüketimleri ve kafein alımlarının değerlendirilmesi. Hacettepe Üniversitesi, Sağlık Bilimleri Enstitüsü Beslenme ve Diyetetik Anabilim Dalı Uzmanlık Tezi; Ankara, 2017.

12. Baysal A. Çayın beslenme ve sağlı̆̆ımızdaki önemi. Standart. 1992:31-42.

13. Acheson KJ, Zahorska-Markiewrcz B, Pittet P, Anantharaman K, Jequirer E. et al. Caffeine and coffee: their influence on metabolic rate and substrat eutilization in normal weight and obese individuals. ASN. 1980;33(5):989-997.

14. WHO. Growth Reference Data for 5-19 years 2014 , http://www.who.int/growthref/who2007 bmi f or age/en Erişim Tarihi:27 Aralık 2018.

15. Serra-Majem L, Ribas L, Perez-Rodrigo C, Garcia-Closas R, Pena-Quintana R, Aranceta J. Determinants of nutrient intake among children and adolescents: results from the enkid study. Ann Nutr Metab. 2002;(1):31-38.

16. Acar TN, Yildiran H, Akbulut G, Bilici S, Köksal E, Gezmen Karadağ M et al. Evaluation of dietary quality of adolescents using healthy eating index. Nutr Res Pract. 2011;5(4);322328.

17. Thompson-McCormick JJ, Thomas JJ, Bainivualiku A, Khan AN, Becker AE. Breakfast skipping as a risk correlate of overweight and obesity in school-going ethnic Fijian adolescent girls. Asia Pac J Clin Nutr. 2010;19(3);372-382.

18. Deshmukh-Taskar PR, Nicklas TA, O'Neil CE, Keast DR, Radcliffe JD, Cho S. The relationship of breakfast skipping and type of breakfast consumption with nutrient intake and weight status in children and adolescents: the national health and nutrition examination survey 1999-2006. J Am Diet Assoc. 2010;110(6):869-878.

19. T.C. Sağlık Bakanlığı Temel Sağlık Hizmetleri Genel Müdürlüğü, Hacettepe Üniversitesi Beslenme ve Diyetetik Bölümü. Türkiye'ye Özgü Beslenme Rehberi, Sağlık Bakanlığ 1 Yayın1, Ankara, 2015.

20. Gazan R, Sondey J, Maillot M, Guelinckx I, Lluch A. Drinking water intake is associated with higher diet quality among french adults. Nutrients. 2016;8:2-23.

21. Brown J, Boer de HI, Robinson-Cohen DS, Siscovick B, Kestenbaum M. Aldosterone, parathyroid hormone, and the use of reninangiotensin aldosterone system inhibitors: the 
multi-ethnic study of atherosclerosis. $J$ Clin Endocrinol Metab. 2015;100:490-499.

22. Lachenmeier DW, Wegert $K$, Kuballa $T$, Schneider R, Ruge W, Reusch $\mathrm{H}$, et al. Caffeine intake from beverages in German children, adolescents, and adults. Journal of caffeine research. 2013;3(1):47-53.

23. Öz F. Adolesanlarda internet destekli beslenme eğitiminin etkinliğinin değerlendirilmesi: randomize kontrollü çalısma. Eskișehir Osmangazi Üniversitesi Tıp Fakültesi, Uzmanlık Tezi; 2015.

24. Onis MD, Onyango AW, Borghi E, Siyam A, Nishida C, Siekmann J. Development of a WHO growth reference for school-aged children and adolescents. Bulletin. 2007;85(9):660-667. 